\title{
PENINGKATAN MOTIVASI BELAJAR SISWA MELALUI LAYANAN BIMBINGAN KELOMPOK
}

\author{
Wahyudin \\ SMP Negeri 2 Simpang Hilir
}

\begin{abstract}
ABSTRAK
Penelitian ini dilaksanakan berdasarkan fenomena yang ada di SMP Negeri 2 Simpang Hilir yang menunjukkan terdapat siswa yang tingkat motivasi belajarnya rendah. Melalui layanan bimbingan kelompok diharapkan motivasi belajar siswa ini dapat ditingkatkan. Tujuan dari penelitian ini adalah untuk mengetahui gambaran motivasi belajar siswa sebelum mendapatkan layanan bimbingan kelompok, untuk mengetahui gambaran motivasi belajar siswa setelah mendapat layanan bimbingan kelompok, dan untuk mengetahui apakah motivasi belajar dapat ditingkatkan melalui layanan bimbingan kelompok.

Jenis penelitian yang digunakan dalam penelitian ini adalah Penelitian Tindakan Bimbingan dan Konseling dengan melaksanakan dua siklus. Subyek penelitian ini yaitu 10 siswa yang terdiri atas 8 siswa bermotivasi belajar rendah dan 2 siswa yang memiliki motivasi belajar tinggi, agar terjadi dinamika kelompok. Metode pengumpulan data yang digunakan yaitu wawancara, skala motivasi belajar dan observasi. Sedangkan teknik analisis datanya menggunakan analisis deskriptif persentase dan kualitatif.

Hasil penelitian menunjukkan bahwa motivasi belajar siswa sebelum memperoleh perlakuan berupa bimbingan kelompok, sebesar 44,4\% kategori rendah. Setelah diberi layanan bimbingan kelompok pada sikus I, motivasi belajar siswa meningkat menjadi kategori sedang sebesar $65 \%$. Sedangkan pada siklus II motivasi belajar siswa terus meningkat menjadi kategori tinggi dengan perolehan sebesar 74\%. Hal ini menunjukkan layanan bimbingan kelompok dapat meningkatkan motivasi belajar pada siswa.
\end{abstract}

Kata Kunci: motivasi belajar, bimbingan kelompok

\section{PENDAHULUAN}

Proses belajar mengajar merupakan proses yang mengandung serangkaian perbuatan guru dan siswa atas dasar hubungan timbal balik yang berlangsung dalam situasi edukatif untuk mencapai tujuan tertentu. Keberhasilan proses belajar mengajar dipengaruhi oleh banyak faktor. Salah satu faktor penunjang keberhasilan belajar yang ditinjau dari siswa yaitu motivasi.

Motivasi sangat menentukan tingkat keberhasilan belajar siswa. Motivasi menjadi salah satu faktor yang turut menentukan belajar efektif dan menentukan hasil belajar yang lebih baik. Menurut Sardiman (2010: 86) motivasi tidak terlepas dari kegiatan belajar mengajar di sekolah, karena tanpa adanya motivasi maka kegiatan belajar mengajar tidak dapat berjalan efektif dan tidak dapat mencapai hasil yang maksimal. Intensitas motivasi seorang siswa akan sangat menentukan tingkat pencapaian prestasi belajarnya. Hal ini karena kurangnya motivasi belajar

dalam diri siswa maka akan berpengaruh pada hasil belajarnya. Siswa akan mengalami penurunan dalam prestasi belajar. Selain itu, juga berdampak tinggal kelas pada kenaikan kelas.

Fenomena di SMP Negeri 2 Simpang Hilir menunjukkan bahwa ada siswa yang memiliki motivasi belajar yang rendah. Berdasarkan hasil wawancara dengan guru pembimbing dan guru mata pelajaran. Dari hasil leger dan hasil 
pengisian skala motivasi, terdapat 8 anak yang memiliki motivasi belajar rendah. Sejalan dengan hasil wawancara dengan guru pembimbing dan wali kelas, diperoleh bahwa siswa yang kurang motivasi dapat dilihat dari tingkah laku seperti malas mencatat, kurang antusias mengikuti pelajaran, sering terlambat mengumpulkan tugas, tidak berani maju di depan kelas, tidak mau bertanya, dan minder dengan teman-teman.

Usaha yang akan dilakukan dalam rangka meningkatkan motivasi belajar siswa yang rendah adalah dengan mengoptimalkan layanan BK kepada siswa. Ada beberapa cara yang dapat dicoba dalam upaya menyelesaikan masalah tersebut, diantaranya pemberian informasi tentang pentingnya motivasi belajar, konseling individu pada siswa yang memiliki motivasi belajar rendah, dan mengadakan bimbingan kelompok.

Dalam penelitian ini, peneliti menggunakan layanan bimbingan kelompok (topik tugas) dengan menggunakan teknik diskusi kelompok. Penggunaan teknik dalam kegiatan bimbingan kelompok mempunyai banyak fungsi selain dapat lebih memfokuskan kegiatan bimbingan kelompok terhadap tujuan yang ingin dicapai tetapi juga dapat membuat kegiatan bimbingan kelompok agar lebih bergairah dan tidak cepat membuat siswa jenuh mengikutinya. Menurut Tohirin (2007: 170) bimbingan kelompok yaitu suatu cara memberikan bantuan kepada individu melalui kegiatan kelompok. Tujuan dari bimbingan kelompok menurut Winkel \& Sri Hastuti (2004: 547) adalah menunjang perkembangan pribadi dan perkembangan sosial masing-masing anggota kelompok serta meningkatkan mutu kerjasama dalam kelompok guna aneka tujuan yang bermakna bagi para partisipan. Selain itu bimbingan kelompok bertujuan untuk merespon kebutuhan dan minat peserta didik sesuai dengan topik yang dibicarakan. Berdasarkan uraian tersebut, penulis tertarik untuk melakukan penelitian tentang peningkatan motivasi belajar dengan judul "Peningkatan Motivasi Belajar Siswa Melalui Layanan Bimbingan Kelompok di SMP Negeri 2 Simpang Hilir".

\section{METODE}

Jenis penelitian yang digunakan dalam penelitian ini adalah Penelitian Tindakan Bimbingan dan Konseling dengan melaksanakan dua siklus. Subyek penelitian ini yaitu 10 siswa yang terdiri atas 8 siswa bermotivasi belajar rendah dan 2 siswa yang memiliki motivasi belajar tinggi, agar terjadi dinamika kelompok. Metode pengumpulan data yang digunakan yaitu wawancara, skala motivasi belajar dan observasi. Sedangkan teknik analisis datanya menggunakan analisis deskriptif persentase dan kualitatif.

\section{HASIL DAN PEMBAHASAN}

Berdasarkan hasil diagnosis kondisi awal, maka peneliti bersama kolabolator memberikan tindakan kepada siswa yang tergolong memiliki motivasi belajar rendah dan beberapa siswa yang memiliki motivasi belajar sangat tinggi berupa layanan bimbingan kelompok. Pemberian tindakan diberikan sebanyak dua siklus terhadap partisipan yang berjumlah 10 siswa yang terdiri atas 8 siswa bermotivasi belajar rendah dan 2 siswa bermotivasi belajar tinggi. Teknik pelaksanaan layanan bimbingan kelompok terdiri dari perencanaan (Planning), tindakan (Action), pengamatan (Observation), refleksi (Reflection). Untuk mengetahui pelaksanaan layanan dan hasil dari layanan bimbingan kelompok pada siswadigunakan alat bantu berupa instrumen skala motivasi belajar, wawancara, dan observasi

Siklus 2 dalam penelitian ini memberikan tindakan, yaitu layanan bimbingan kelompok dan bertujuan untuk menyempurnakan hasil siklus 1 . Perbedaan siklus 1 dan siklus 2 terletak pada dinamika 
kelompok. Jika pada siklus 1 menggunakan permainan secara individu, maka pada siklus 2 ini menggunakan permainan yang membutuhkan kerjasama dan berkaitan dengan topik.

Berdasarkan hasil penelitian meningkatakan motivasi belajar siswa pada siswa kelas VIII SMPN 2 Simpang Hilir melalui layanan bimbingan kelompok didapat hasil bahwa motivasi belajar siswa dapat ditingkatkan melalui layanan bimbingan kelompok. Layanan bimbingan kelompok ini dilaksanakan sebanyak dua siklus. Siklus 2 digunakan sebagai penyempurna pada siklus 1. Pelaksanaan layanan bimbingan kelompok diikuti oleh 10 anggota kelompok dan peneliti sebagai pemimpin kelompok. Anggota kelompok terdiri dari 8 siswa yang memiliki motivasi belajar rendah dan 2 siswa yang memiliki motivasi belajar tinggi.

Setelah diberikan layanan bimbingan kelompok pada siklus 1 sebanyak 3 kali pertemuan dengan metode ceramah dan diskusi selama tiga hari dan diakhiri dengan pengisian skala motivasi belajar guna mengetahui tingkat motivasi belajar saat itu, diketahui dari hasil analisis terjadi peningkatan pada motivasi belajar siswa rata-rata menjadi $65 \%$ pada kategori sedang.

Meskipun sudah ada peningkatan pada tingkat motivasi belajar siswa setelah diberikan layanan bimbingan kelompok pada siklus 1, namun hasil rata- ratanya masih dalam kategori sedang. Oleh karena itu, peneliti perlu dilakukan siklus 2. Dalam siklus 2 ini peneliti dengan kolaborator menyepakati akan melakukan siklus 2 dengan 3 kali pertemuan lagi.

Refleksi dari siklus 1 digunakan sebagai acuan dalam merancang dan melaksanakan siklus 2. Pada siklus 2 peneliti tetap menggunakan ceramah dan diskusi, namun yang berbeda adalah dinamika kelompok dengan menggunakan permainan yang membutuhkan kerjasama antar anggota kelompok dan berkaitan dengan materi tips meningkatkan motivasi belajar, pengaruh motivasi belajar terhadap prestasi akademik, dan kreativitas belajar. Siklus 2 dilaksanakan selama 3 kali pertemuan, pada pertemuan ketiga diakhiri dengan pengisian kembali skala motivasi belajar untuk mengetahui tingkat motivasi belajar siswa setelah diberikan layanan bimbingan kelompok pada siklus 2. Hasil analisis terjadi peningkatan rata- rata tingkat motivasi belajar siswa menjadi $74 \%$ pada kategori tinggi.

Berdasarkan hasil pelaksanaan layanan bimbingan kelompok pada siklus 1 dan siklus 2, motivasi belajar siswa menjadi meningkat. Hal ini dibuktikan hasil perhitungan deskripsif persentase skala motivasi belajar menunjukkan peningkatan yang signifikan. Sebelum diberikan tindakan berupa layanan bimbingan kelompok rata-rata siswa tingkat motivasi belajarnya dalam tingkat rendah, namun setelah diberikan layanan bimbingan kelompok selama 6 kali pertemuan rata-rata tingkat motivasi belajar siswa menjadi tinggi.

Selain dari hasil perhitungan deskriptif persentase skala motivasi belajar, peningkatan siswa juga dapat terlihat dari hasil observasi yang dilaksanakan selama kegiatan belajar mengajar di kelas dengan bantuan guru pembimbing sebagai kolaborator. Peningkatan siswa yang dapat terlihat antara lain adalah siswa menjadi lebih berani dalam berpendapat, siswa lebih rajin dalam mengerjakan tugas-tugas, siswa lebih tepat waktu dalam mengumpulkan tugas, siswa terlihat lebih bersemangat mengikuti kegiatan belajar mengajar, dan lain sebagainya.

Hal tersebut menunjukkan bahwa tingkat motivasi belajar siswa pada di SMP Negeri 2 Simpang Hilir meningkat setelah mendapatkan layanan bimbingan kelompok. Dengan kata lain motivasi belajar siswa 
Jurnal Inovasi BK,Volume 2, Nomor 1 Juni 2020

dapat ditingkatkan melalui layanan bimbingan kelompok yang tepat.

\section{KESIMPULAN}

Kondisi awal tingkat motivasi belajar dari 18 siswa yang mengisi skala motivasi belajar dapat diketahui $50 \%$ dengan jumlah 9 siswa memiliki motivasi belajar tinggi, 5,5\% dengan jumlah 1 siswa memiliki motivasi belajar ketegori sedang, dan 44,4\% dengan jumlah 8 siswa memiliki tingkat motivasi belajar rendah. Dari hasil skala motivasi belajar dan wawancara dengan klien yang memiliki tingkat motivasi belajar rendah, diketahui bahwa siswa menunjukkan perilaku seperti : malas mencatat, kurang antusias mengikuti pelajaran, sering terlambat mengumpulkan tugas, tidak berani maju di depan kelas, tidak mau bertanya, dan minder dengan teman-teman.

Tingkat motivasi belajar siswa setelah diberikan layanan bimbingan kelompok pada siklus 1 mengalami peningkatan mencapai rata-rata $65 \%$ menunjukkan kategori sedang. Sedangkan peningkatan motivasi belajar setelah diberikan layanan bimbingan kelompok pada siklus 2 mengalami peningkatan ratarata $74 \%$ pada kategori tinggi.

Ada perbedaan yang signifikan dalam motivasi belajar siswa sebelum dan setelah diberikan tindakan, dimana terjadi peningkatan motivasi belajar setelah diadakan layanan bimbingan kelompok. Secara garis besar dapat disimpulkan bahwa layanan bimbingan kelompok yang tepat dapat digunakan untuk meningkatkan motivasi belajar siswa di SMP N 2 Simpang Hilir.

\section{DAFTAR PUSTAKA}

Hidayat, Dede Rahmat dan Aip Badrujaman. 2012. Penelitian Tindakan dalam Bimbingan Konseling. Jakarta: PT Indeks Permata Puri Media
M, Sardiman A. 2010. Interaksi dan Motivasi Belajar Mengajar. Jakarta: Raja Grafindo Persada.

Mahmud, Hasan. 2012. Pengembangan Model Bimbingan Kelompok Berbantuan Media Audiovisual Untuk Meningkatkan Motivasi Belajar Siswa Kelas VIII SMP Muhammadiyah 1 Kudus. Tesis : UNNES.

Romlah, Tatiek. 2001. Teori dan Praktek Bimbingan Kelompok. Malang : Universitas Negeri Malang.

Setyaningtyas, Hidayah Ratna. 2012. Meningkatkan Motivasi Belajar Rendah pada Siswa Kelas IX F melalui Konseling Rasional Etimotif di MTs Negeri Lasem Tahun Pelajaran 2011/2012. Skripsi: UNNES.

Slameto. 2010. Belajar dan Faktor-faktor yang Mempengaruhinya. Jakarta : Rineka Cipta.

Sudjana, Nana. 2009. Penilaian Hasil Proses Belajar Mengajar. Bandung : Remaja Rosdakarya.

Sukiman. 2011. Penelitian Tindakan Kelas untuk Guru Pembimbing. Yogyakarta: Paramitra Publishing.

Suryabrata, Sumadi. 2011. Psikologi Pendidikan. Jakarta: Raja Grafindo Persada.

Tadjri, Imam. 2010. Penelitian Tindakan Bimbingan dan Konseling. Semarang: Widya Karya Semarang.

Uno, Hamzah B. 2010. Teori Motivasi dan Pengukurannya. Jakarta: Bumi Aksara.

Sugiyono. 2007. Statistik untuk Penelitian. Bandung: Alfabeta.

Keke T. Aritonang. 2014. Minat dan Motivasi dalam Meningkatkan Hasil Belajar Siswa (Jurnal Pendidikan. https://d1wqtxts 1 xzle7.cloudfront.ne t/35904799/Hal. 11-

21_Minat_dan_motivasi_belajarwith-cover-page-v2.pdf) diunduh 11/08/2018. 
S. Eko Putro Widoyoko, Anita Rinawat. 2012. Pengaruh Kinerja Guru Terhadap Motivasi Belajar Siswa. (Jurnal pendidikan. https://journal.uny.ac.id/index.php/c $\mathrm{p} /$ article/view/1563 ) diunduh 11/08/2018.

Aidha, Harners. 2013. Penerapan Bimbingan Kelompok dengan Teknik Diskusi Kelompok untuk meningkatkan Motivasi Belajar Siswa Kelas VIII D SMP N 1 Ngariboyo (jurnal pendidikan.http://www.scribd.com/d oc/156105541 \#download(diunduh $05 / 06 / 18)$

Djahrudin, dan Rini Fatmawati.2006. Penerapan Strategi Pembelajaran untuk Meningkatkan Motivasi Belajar Siswa SD pada Mata Pelajaran IPS (jurnal pendidikan). Vol7, No2 http:/jurnal.pdii/lipi.go.id/admin/jur nal/ 1020899110.pdf (diunduh20/05/18)

Tina Aflatin, Sri Mulyanl Martanlah. 1998. Peningkatan Kepercayaan Diri Remaja Melalui Konseling Kelompok ( Jurnal Pendidikan. https://journal.uii.ac.id/Psikologika/a rticle/download/8466/7192 diunduh 11/08/2018.

Sigit Sanyata. 2010. Teknik Dan Srategi Konseling Kelompok ( Jurnal Pendidkan:

https://journal.uny.ac.id/index.php/p aradigma/article/view/5918 diunduh 11/08/2018.

Mardia Bin Smith. 2011. Pengaruh Layanan Konseling Kelompok Terhadap Disiplin Belajar Siswa Di Sma Negeri 1 Atinggola Kabupaten Gorontalo Utara ( Jurnal Pendidikan: https://d1wqtxts1 xzle7.cloudfront.ne t/35088750/MARDIA_OK diunduh 11/08/2018.
S Suprihatin, 2015. Upaya guru dalam meningkatkan motivasi belajar siswa. (Jurnal Pendidikan: https://ojs.fkip.ummetro.ac.id/index. php/ekonomi/article/view/144 ) di unduh 11/08/2018. 